\title{
The same, only different: Doing management in the intersection between work and private life for men and women in small-scale enterprises
}

\begin{abstract}
The aim of this article is to elucidate how male and female managers of small-scale enterprises in Norway and Sweden relate to and experience the intersection between work and private life. A qualitative content analysis was adopted to explore interviews with 18 managers. The analysis resulted in three primary categories: conflict as a part of the deal, using management to construct balance, and management identity contributing to enrichment. A key theme that emerged was doing management. Both men and women reproduced masculine values in describing their management identity and in explaining how they enacted management. This clear identification was used to legitimate conflict, construct balance and explain the interaction between work and private life as enriching. How the managers enacted gender emerged primarily in how they related to family responsibilities and their feelings of guilt in relation to home and children.
\end{abstract}

$\underline{\text { Key words: }}$ gender and management, enacting management roles, work-life balance, worklife conflict, work-life enrichment, small-scale enterprises

Emma Hagqvist ${ }^{1,2^{*}}$, Stig Vinberg ${ }^{2}$, Jonathan Q. Tritter ${ }^{3}$, Erika Wall ${ }^{2}$ and Bodil J. Landstad ${ }^{2,4}$

1. Stress Reseach Institute, Stockholm University, Stockholm, Sweden

2. Department of health sciences, Mid Sweden University, Östersund, Sweden

4. School of Languages and Social Sciences, Aston University, Birmingham, United Kingdom

4. Levanger Hospital, Nord-Trøndelag Hospital Trust, Norway,

* Corresponding author

Emma.Hagqvist@su.se

Stress reseach institute

Stockholm university

SE-106 91 Stockholm 


\section{Introduction}

Managers in small-scale enterprises (SSEs), whether owned by the manager or someone else, are particularly at risk of high work demands and the challenges of balancing these with a private life (Stephan, 2018). The majority of the research evidence in this area shows that the risk of experiencing conflict between work and private life is exacerbated by long working hours, high job demands, high workload and high work responsibility (Eurofound, 2017; Nordenmark, Vinberg, and Strandh, 2012), all of which managers in SSEs often face (Stephan, 2018). Despite research evidence of the conflict in balancing work and family responsibilities among managers, little is known about how managers understand this stress and experience the interface between their work and private life (Annink, Den Dulk and Amorós, 2016). To the best of our knowledge, no qualitative study has been conducted exploring this phenomenon in a Scandinavian context.

Scandinavian countries (e.g., Norway and Sweden) are often seen as fairly gender-equal (Thévenon, 2011), and a larger proportion of women work in Scandinavian countries than in other European countries (The European Institute for Gender Equality, 2013). Because of the stress on gender equality and well-developed family policies, it is argued that Scandinavians experience less conflict between their work and private life. Indeed, some studies support this argument (Strandh and Nordenmark, 2006; van der Lippe, Jager and Kops, 2006), while others suggest the opposite (Boye, 2011; Lunau et al. 2014). Likewise, some scholars conclude that few women in Scandinavia use self-employment to balance work and their family life and that they therefore should experience lower levels of conflict (Hilbrecht and Lero, 2014). However, statistical evidence shows that both men and women in Norway and Sweden perceive difficulties in meeting the combined demands of working life and private life (Duvander, Lappegard and Andersson, 2010; Hagqvist, Gillander Gådin, and Nordenmark, 2017) and that managers, compared to regular employees, may be at higher risk of experiencing conflict (Hagqvist, Toivanen, and Vinberg, 2015; Nordenmark et al., 2012; Hagqvist, Toivanen, and Bernhard-Oettle, 2018). Based on interviews with 18 managers of SSEs (with fewer than 20 employees) in Norway and Sweden, this article contributes to this debate and to evidence from previous international studies by providing insights into how Scandinavian managers experience and relate to the intersection between work and private life.

There is an assumption that in Scandinavian countries, gender equality and the family-friendly dual-earner context results in men and women sharing child care responsibilities and housework more equally. In Sweden, however, the political discourse on gender equality tends to focus on individual participation in the labour market and less on equal conditions at work or in accessing work (Carbin, Overud and Kvist, 2017; Hagqvist, 2016). For instance, in the political discussions of gender equality, the focus is on women's rights to full-time work while their responsibilities in the home, such as housework, are neglected (Carbin et al. 2017); these discussions therefore fail to engage with gender relations. For women, this results in the dual burden of work and the home; what Hochschild and Machung (2003) refer to as women working a 'second shift'. Given Scandinavian social norms that hold all individuals responsible for contributing to the welfare system by working, and a gender-equal discourse on paid work, it is important to understand how managers of SSEs relate to the intersection between work and private life.

Research suggests that having a managerial position in an SSE often involves long and irregular working hours (Gunnarsson, Vingård and Josephson, 2007; Landstad, Hedlund, and Vinberg, 2017; Nordenmark et al., 2012), high and work demands (Bornberger-Dankvardt, Ohlson and Westerholm, 2003; Landstad et al., 2017; Stephan and Roesler, 2010) and significant time strain (Hagqvist et al., 2015). On the other hand, studies show that managers 
have significant decision making autonomy and can control how their work is organized (Hundley, 2001; Nordenmark et al., 2012; Stephan and Roesler, 2010). Although managers experience longer working hours and heavier work demands than regular employees, they generally experience richer working lives and exhibit higher measures of self-determination, freedom and autonomy (Beutell, 2007; Nordenmark et al., 2012; Stephan and Roesler, 2010), which have implications for balancing the often conflicting demands of work and private life.

This article explores how male and female managers of SSEs in Norway and Sweden relate to, and experience, the demands of work and private life.

In the literature, different terms are used to describe business ownership with or without employees (Henrekson and Stenkula, 2009). Foremost among these terms are 'entrepreneur' and 'self-employed', which are sometimes used interchangeably and often without describing specifically an ownership situation. There also exist differences in the definition of business types. One way of defining businesses is by the number of employees; SSEs are those businesses that employ 10 to 20 people (European Union, 2003).

This article is based on a study of men and women who manage SSEs, including those who manage and operate them as small businesses but are not necessarily owner-operators. Although owning a business differs somewhat from managing on behalf of an owner, both roles are central to shaping the strategy and operational direction of a company, and the opinions and values of the people who hold these roles influence business goals and workplace health issues (Hasle and Limborg, 2006). The leadership position held by managers of SSEs, independent of their ownership situation, is very similar. Much of the research literature about working conditions and the balance between work and private life focuses primarily on self-employed individuals or entrepreneurs and not on managers of SSEs. Our research contributes to filling this gap in the literature and applies the existing evidence concerning entrepreneurs and the self-employed to describe and problematize the demands of work and private life for managers of SSEs in Norway and Sweden.

\section{Gender and management}

The gender order is embedded in daily life, work and private life, family, organizations and institutions, the labour market and society as a whole (Acker, 1990, 2006; Hagqvist, 2016; Härenstam, 2009). Similarly the gender order is shapes what we do and wear, how we present ourselves (Acker, 1992; West and Zimmerman, 1987) and how we are viewed (Connell, 2009). Through this replication, gender, as a social construction, is constantly produced and reproduced. Work is one arena where the reproduction of gender through social and material relations occurs and is constituted in asymmetric power relations and inequalities (West and Zimmerman, 1987). Work is an act of 'doing gender' where women and men 'whose competence as members of society is hostage to its production' (West and Zimmerman, 1987 p. 125). As hostages to gender, men and women have different opportunities to access and participate in the labour market, paid work, careers and managerial positions. Gender also affects how women and men relate to work, resulting in what Acker suggests is an inequality regime in the institution of work (Acker, 2006); an regime that is also apparent in people's private lives outside of work.

Management and leadership are constructed within these inequality regimes (Acker, 2006; Fogelberg Eriksson, 2016; Holmquist and Sundin, 2002) and hegemonic masculinity is a characteristic and aptitude of the ideal manager: a leader who is strong, technically competent, entrepreneurial, and authoritative (Acker, 1990; Holmquist and Sundin, 2002). Of relevance is the fact that men are far more numerous in management positions. As such, management is masculine and a form of male and masculine capital (Huppatz, 2009). Huppatz (2009) 
suggests that Bourdieu's concept of 'capital' can be understood in relation to gender. She builds on the previous literature discussing gender and capital by introducing both feminine and female capital and masculine and male capital. Female or male capital is the leverage a female or male body can have. Feminine and masculine capital are the advantages that follow from the social construction of femininities and masculinities. The masculine norm in management might cause both men and women to make adjustments to how they manage and balance work in relation to their private life.

\section{The intersection between work and private life}

The intersection between work and private life - work-life - generates feelings that Greenhaus and Beutell (1985) and later Greenhaus and Powel (2006) have labelled conflict and enrichment. The concept of 'work' is often straightforward, while the definition of 'life' is narrower and more diffuse. The term 'life' usually conveys domestic work, children and family (Eikhof, Warhurst and Haunschild, 2007). This narrow definition of life creates limitations and exclusions (Wilkinson, Tomlinson and Gardiner, 2017). Life outside work consists of more than care; thus, in this article, private life refers to time outside of work.

The idea of the conflicting demands of work and private life builds on role stress theory, recognizing the multiple burdens of being a parent, family provider, worker, manager, friend and family member (Greenhaus and Beutell, 1985). Thus, when an imbalance between different roles in the private and work spheres exists, conflicts arise. Scholars define two different conflict directions: work interfering with private life (work-life conflict) and private life interfering with work (life-work conflict).

Evidence indicates that men and women generally perceive higher levels of work-life conflict than life-work conflict (Byron, 2005; Fahlén, 2014). However, it has been recognized that among self-employed workers, both directions of conflict are apparent (Beutell, 2007). Demands in the home, such as stress related to time spent on housework and childcare, increase the risk of reporting life-work conflict (Byron, 2005; Fahlén, 2014). Risk factors for the onset of work-life conflict include long working hours, working unsocial hours, an unemployed partner, job demands, poor psychosocial work environment, having a professional job, and parenthood (Bianchi and Milkie, 2010; Crompton and Lyonette, 2006; Fahlén, 2014; Grönlund, 2007b; McGinnity and Calvert, 2009). On the other hand, job control and support at work seem to have a protective effect on the experience of work-life conflict (Engman, Nordin and Hagqvist, 2017; Grönlund, 2007b).

There appear to be gender differences in the experience of conflicting demands; men seem to experience higher levels of work-life conflict, while women higher levels of life-work conflict (Fahlén, 2014). Furthermore, gendered expectations of work tasks seem to explain some of the differences in levels of conflict among men and women (Fahlén, 2014). For example, unsocial working hours, no flextime (Fahlén, 2014) and long working hours (McGinnity and Calvert, 2009) have a greater impact on women's levels of work-life conflict than on men's. A worker's ability to plan and exercise control over work and home responsibilities appears to reduce conflict; this reduces perceptions of work-life conflict and has a stronger impact on women compared to men (Grönlund, 2007b).

Literature suggests that those who own and manage a business seem to experience more conflict in the demands of work and private life than regular employees (Johansson Sevä and Öun, 2015; Nordenmark et al., 2012). On the other hand, these individuals, due to greater job control, are more able to allocate their time than employees and therefore are better able to balance work-life demands (Nordenmark et al., 2012). When interviewed, self-employed workers describe their capacity to exercise control over their time as an important aspect of 
managing their own business (Hilbrecht and Lero, 2014). On the other hand, when asked to elaborate on their working and private life, self-employed people disclose feelings of being 'always on', working long hours, constantly developing the company, marketing, seeking new opportunities or worrying about income (Hedlund, Landstad and Vinberg, 2017; Hilbrecht and Lero, 2014). Annink (2017) concludes that owner-manager status compels men and women to draw a line between work and private life. Thus, the benefits that are gained in the ability to balance work and private life commitments by having a managerial position may be outweighed by the responsibilities of being an owner-manager (Bunk, Dugan, D'Agostino and Barnes-Farrell, 2012), and this may be enacted differently by men and women.

Work-life balance is often used to describe a healthy and sustainable lifestyle; the opposite of work-life conflict. In recent years, the concept of work-life enrichment has emerged as an explanation of how one role can improve the quality and performance of other roles (Greenhaus and Powell, 2006). It has been suggested that enrichment can have a buffering effect on the conflicting demands of work and family (Gareis, Barnett, Ertel and Berkman, 2009). Enrichment and conflict may exist in parallel, and individuals can be impacted by more than one consequence of managing the competing demands of work and home life. Greenhaus and Powell (2006) suggest two pathways for enrichment: i) the affective path, where resources generated in one role can promote positive effects in the same role and, in turn, this produces high performance and positive consequences for another role; and ii) the instrumental path, where the application of resources in one role has a direct, influential effect on another role. For instance, income from work can be used to fund a family holiday that can have a positive effect on productivity, as it provides time for recovery and spending time with loved ones. Beutell (2007) studied the factors that predict the existence of both conflict and enrichment among self-employed people and found that factors that increased conflict also increased feelings of enrichment.

In summary, as the ideals of management favour masculine and male capital, according to Huppatz (2009; p. 59) management could 'de-legitimate feminine and female capitals and nullify their strategic usefulness'. Management can also require women managers to make adaptations that compromise feminine responsibilities in the domestic sphere (Acker, 2006). However, as Bourdieu (2001 in Huppatz, 2009: p.59-60) has suggested, if women 'behave like men, they risk losing the obligatory attributes of 'femininity' and call into question the natural right of men to positions of power; if they behave like women, they appear unfit for the job'. This suggest that women need being good managers or being feminine. In this study, carried out in a fairly gender equal context, we challenge this notion. Instead, we intend to complement and extend Huppatz and Acker by showing how both men and women can be good managers while trying to balance work and private life; a balance that is possible because of their gender capital.

\section{Methodology}

In this article, interview transcripts from managers in 18 SSEs in the central regions of Norway and Sweden were analysed. All respondents participated in a project on workplace health management (WHM) that aimed to improve manager's skills and competence in health and work environment issues. This article focuses on what managers reported about the intersection between their work and private life.

To ensure a wide range of SSE manager types in the sample, managers were purposively recruited from different parts of the private sector. Informants were recruited from SSEs who agreed to participate in the WHM project. The selection criteria were that the enterprises had no more than 20 employees each, that the enterprises employed both men and women, that they were located in the middle part of Norway or Sweden (from comparable geographic 
regions), and that they represented different types of services within the private sector (see Table 1).

[Insert Table 1 here]

Interviews were conducted between March and May 2015. The interviews lasted from 90-120 minutes and took place at locations convenient to the individual participants (Patton, 2002). All of the managers chose to be interviewed at their own workplace.

Data were collected using focused informant interviews (Denzin, 2001) based on a semistructured interview guide. All interviews were audio-recorded and transcribed verbatim immediately following data collection. Interviews were conducted in Swedish and all citations presented in the paper have been translated from Swedish to English by a native English speaker familiar with the Swedish language.

The interviewer asked about the manager's experiences and reflections on management policy, opportunities and obstacles to creating a healthy workplace, work-life balance, and the implementation of workplace health management in their enterprise. This article reports the findings of these interviews in which male and female managers of SSEs discussed their experiences and how they handled the demands of their work and private life.

In this article, a qualitative content analysis was carried out to identify empirically driven codes and categories and a unifying theme, as defined by Graneheim and Lundman (2004) and Graneheim, Lindgren and Lundman (2017). Content analysis moved from manifest, close-to-the-text descriptions and interpretations of latent content to those that are more distant from the text but are still close to participant's reality (Graneheim et al., 2017). An initial reading of each transcript identified a unit of analysis defined as the narrative account, which concerns the intersection between work and private life, resulting in a significant amount of material. The unit of analysis was read through several times to obtain a sense of the whole. The analysis was performed in several steps. 1) Three content areas were identified based on theoretical and empirical understanding of the concepts of work-life conflict (Greenhaus and Beutell, 1985), enrichment (Greenhaus and Powell, 2006) and work-life balance. 2) Meaning units within each content area were identified and each given a code. 3) Codes were compared to identify similarities and differences. The codes were then grouped into sub-categories sharing the same characteristics and then placed into three categories. 4) Through reflection and discussion between the authors, one theme unifying the content of the categories was formulated. Although the analyses are described as linear, the analysis process involved an abductive approach moving back and forth in the text (Graneheim et al., 2017; Graneheim and Lundman, 2004) until saturation was reached, meaning that the narratives yielded no further information (Polit and Beck, 2004). The NVivo (7.0) qualitative data analysis package was utilized to code and organize the material.

The Regional Ethical Committee of the Department of Medical Research, reviewed the study and raised no objections from an ethical point of view [Dnr 2014-28-31M]. The informants gave written consent to participate in the study. The informants received information about their ability to withdraw from the study without giving any reason. The material was immediately anonymized, and all identifying data in the transcriptions of the interviews were removed.

\section{Findings and discussion}

Although not the primary focus of the interviews, managers presented their experiences of the interface between work and private life. When asked about their working conditions, managers responded by discussing not only heavy workloads, high demands and strain but 
also satisfaction. In the interviews, terms such as work, time, home, leisure-time (or time outside work), children and working conditions were central in explaining the interface between work and private life and how these different spheres of life were linked. This was interesting, as it illustrated how, for the managers, private life was interwoven with work. In the interviewe data, we identified one overarching theme, and three categories (see Table 2). The theme was doing management. The three categories were conflict as a part of the deal, using management to construct balance, and management identity contributing to enrichment. Although the categories were exclusive, a clear identification as both a manager and one who does management was apparent throughout all of the categories.

[Place Table 2 here]

\section{Theme: Doing management}

The managers, both men and women, identified with their work, and as managers of an SSE; a clear role identity. This contrasted with a more latent management identity that was less explicit but apparent in how they discussed and related to their management roles and the interface between work and private life. Management was a part of who they were and was constantly present in their stories. One female manager expressed how she related to management,

'I could work less if I wanted to, but I want to work. I am self-employed because I like this, to operate, develop and engage with others.' (Woman [IP9])

Doing management signified the extent to which the managers seemed to embody or selfenact the management role. Management was not something they stepped in and out of, it was a persistent part of who they were. The accounts of the respondents also illustrated how they reproduced masculine capital when they were 'doing management', which tended to affect the way they understood and discussed their work and private life. We go on to consider the empirical evidence of doing management in relation to each category.

\section{Category: Conflict as a part of the deal}

The first analytical category relates to how conflicting demands between work and private life were expressed as a natural aspect of the SSE managerial role by both men and women. Managers in this study reported a high workload, significant responsibility and long working hours, all of which align with previous research (Hagqvist et al., 2015). In previous studies, self-employed workers and managers referred to the concept of being 'always on' to describe their boundless work (Hilbrecht and Lero, 2014; Landstad et al., 2017). The feeling of being 'always on' was also apparent in our data. Two of the managers explained:

'You are always on, you are always available.' (Woman [IP10])

'They unite, sometimes I have to work evenings and weekends. [...] In my spare time I think a lot about work, make plans. There is no clear line between work and private life. They unite.' (Man [IP5])

Meanwhile, interviewees seemed to justify being 'always on' and the lack of distinction between work and private life as an expectation of being a manager of an SSE; it was 'part of the deal' or the 'name of the game'. Long working hours, including evenings and weekends, were talked about as something normal rather than an example of extreme job demands.

Respondents seemed to find their responsibility as managers a reason to prioritize work before family or private life. For instance, when employees called in sick late at night, the managers were obliged to implement a solution for the next morning; an activity and responsibility that 
was not viewed as work. In normalising their heavy workloads, managers were doing and redoing management. Furthermore, masculine capital in management was emphasized. Women managers also adhered to these norms and thus contributed to reproducing masculine capital in management (cf. Acker, 1990; Huppatz, 2009). This aligns with previous work (Annink, 2017) based on interviews with 50 self-employed men and women, that found clear job identification seemed to blur the line between work and private life. As one woman manager in our research explained,

\section{'Sometimes, too much leisure time is used [for work]. I think so. But I don't want to change} either.' (Woman [IP9])

In doing management, hard work was both legitimized and normalized; however, conflict with private life were still evident in the narratives. Conflict was primarily experienced as guilt towards home and family, especially by the female respondents. In the respondents' accounts, gender was deeply embedded, as women and men seemed to conform to typical gender identities within the family. Meanwhile, management was put first, and, as Acker (1990) postulates, by adopting masculinity, women made 'irrelevant everything that makes them women' (p.153). The women interviewed described a lack of time in relation to, for instance, housework, exercising or spending time with children. Lack of time, however, was never mentioned in relation to work, because of the responsibilities of private life. Prioritizing work time confirmed the masculine capital in doing management (cf. Hupptaz, 2009).

Although there is underlying gender equality in Scandinavian countries, houswork is still very much associated with and an expression of feminine values (Carbin, Overud and Kvist, 2017; Hagqvist 2016). Thus, female managers' capital was utilized; however, their capital operated within the constraints of the home (Huppatz, 2009) and was expressed as guilt and stress. Two female managers explained,

'I am stressed because I can't do everything at home. You have clothes, food and a house to maintain [...] I can't do it all, I can't. I have no chance.' (Woman [IP15])

'It's serfdom, that's how it is. Since I started in this company in 2007, I have never had time off. I've never been mentally off work.' (Woman [IP10])

Women without children asserted that if they had responsibility for small children at home they would be unable to fulfil their role as managers, supporting the idea of masculine capital in doing management. One woman explained,

'If I would have had small children at home, I would never have been self-employed.' (Woman [IP9])

Men mentioned tensions relating to time outside work to a lesser degree than women did, and when time outside of work was mentioned, it was seldom related to a situation that created stress or guilt.

'I am a coach for my sons' football team, and that takes time. And they [the children] have other activities where you are expected to take part and be involved. It is a lot of work [...] you have to take them to activities and you want to be there, but there is a lot you need to do.' (Man [IP1])

In their narratives, the dominance of masculine capital (Huppatz, 2009) in management was evident. The female managers cut themselves off from their feminine self by prioritizing work rather than creating a work arrangement around their female capital. In doing management, they unintentionally also adjusted to the dominant masculine capital. Although guilt was felt towards the home, it was secondary to their identification as managers. It became evident that 
the feminine capital had no strategic usefulness in doing management and that masculine capital prevailed in the SSEs we studied.

\section{Category: Using management to construct balance}

The second analytical category identified relates to how managers use their situation to balance calls on their time at work and at home. In respondent's accounts, experiencing conflict and constructing balance coexisted and a personal identification as managers contributed to this duality. Respondents explained that their work as managers of SSEs gave them control over their work situation and that this provided a mechanism for balancing the competing demands of their private life and their work. The flexibility and the ability to control work time was mentioned as an advantage of being a manager of an SSE, supporting previous findings (Hilbrecht and Lero, 2014). Managers described the flexibility in their role as a source of pride and one that created the autonomy to decide what to do and when to do it. Having flexibility strengthened their capacity to manage and making use of flexible work had become a way of doing management. One male manager explained that

\section{'[...]flexibility and freedom are most valuable in this work.' (Man [IP2])}

Exercising flexibility has been found to be gendered; men and women managers describe and use control in different ways (Annink, 2017; Loscocco, 1997; Wheatley, 2017). For female managers in these studies, control meant flexibility to adapt work to family responsibilities, while male managers described flexibility as a way to work more (Ibid.). In contrast with those studies, we found that both male and female respondents in our research explained flexibility as a way to spend more time at work. Hilbrecht and Lero (2014) refer to the concept of fitting work around family as a way of explaining how flexibility permits the balancing of competing commitments. Female and male managers in this study, particularly those with children, explained different strategies for how they used the flexibility that came with managing an SSE to fit work around their family commitments. For example, some managers described bringing their computer or phone home so that they could work at night when their children were in bed. For these respondents, this was a flexible way of working that they perceived as creating balance. One woman manager said,

'I can go and come as I like, some days anyway. The balance is great. I can bring the machine [computer] home if I need to do something. It happens that I do that a lot. The balance is good.' (Woman [IP12])

Some managers had shared parenting arrangements, and their children lived with them every second week. They used their managerial flexibility to arrange work during the weeks when their children stayed with the other parent. One manager who was also a father explained,

'I sometimes have to work nights and weekends. But... I have my children every second week and then I try to work less ... or I do work less, I don't work nights and weekends when I have my children. So, the weeks when I don't have the kids I work more.' (Man [IP5])

Although flexibility was mostly mentioned by parents as a way to fit work around family, it was also mentioned by others as a way to create space for leisure activities and relaxation. As one respondent noted,

'I don't feel a need for holidays [...] the feeling of knowing that on a beautiful winter day I can stop working and go skiing, which make me feel the need for longer holidays.' (Man, [IP2]) 
Although IP2 mentioned flexibility in relation to skiing, he also told us he had no need (nor time) for holidays and often worked weekends. The flexibility he mentioned was thus limited and seemed to reaffirm his management role.

In our study, there was no apparent gender difference in how the managers used flexibility to balance their commitments. Flexibility primarily meant creating space for more work for both the men and the women interviewed. Flexibility could also be understood as a way women strategically used and gained masculine capital needed to do management; they used their flexibility as managers to fit work around family needs, rather than the other way around (Annink, 2017; Hilbrecht and Lero, 2014). However, women managers while using their flexibility as managers, still expressed this as enhancing balance in their lives.

\section{Category: Management identity contributing to enrichment}

The third and final analytical category identified perceptions of enrichment for the men and women managers interviewed. Several descriptions of work-life enrichment in light of their identification as managers were distinct. Greenhaus and Powell (2006) described two types of enrichment paths, instrumental and affective, reflecting the opportunity to deploy resources derived in one role to produce either a direct or indirect positive effect on that role, in turn creating a positive impact on another role.

Identification as managers gave respondents self-esteem that produced a positive effect in relation to work. The positive emotions constructed through their identification with work enriched them as individuals, workers and family members. As one manager suggested,

\section{'I have never done anything else. I have always had much to do. But I don't think I could have done anything else, I wouldn't want to have it any other way.' (Man [IP 18])}

Other instrumental enrichment paths identified in the data also seemed to strengthen managers. Some had help within the home sphere that enabled them to carry out better their managerial responsibilities. An example of this included support from parents and grandparents to take care of children, enabling a manager to spend more time at work. One respondent described how his partner worked as a director in a government authority concerned with healthy work environments and that he could draw on her knowledge in his own work as a manager. Work that instrumentally enriched private life was primarily discussed in terms of financial support. For example, after working long hours that took time away from family, the extra money earned could be used to pay for family holidays.

Affect enrichment seemed to be mostly associated with social support. Social support has previously been identified as a factor that buffers the impact of conflicting demands of work and family (Annink, 2017; Grönlund, 2007a; Hedlund et al., 2017). Social support from colleagues and supervisors could enable individual wellbeing, but these sources were far less available to managers (Luchman and González-Morales, 2013). However, in a study by Hedlund et al. (2017), several managers explained that their board provided guidance and advice on how to develop their business and that board members provided important social support to them personally. Social support, to the best of our knowledge, has never been discussed in relation to work-life enrichment. Managers in this study explained that social support and their social context outside of work were positive; something that gave them energy but also helped them balance the competing demands on their time. Friends and family outside work were a potential source of both emotional and instrumental support; this aligns with previous research showing that family relationships can be an important resource for managers (Hedlund et al., 2010; Parasuraman, Purohit, Godshalk and Beutell, 1996). A primary benefit of social support may be that among friends and family, managers, and especially women managers, can relax from their responsibilities. 
'It is great to have friends. They know me. They see me differently than my employees, and they have given me support. They can see and ask 'How are you?' or 'now we have to do something fun'. I can talk to them about all the shit and be done with it. Then everything feels much better.' (Woman [IP9])

Among family and friends, female managers did not need to enact clear job identification. They did not need to do management, but instead were allowed to be their feminine selves and use their female capital. Being able to be themselves gave women managers energy and enabled them to cope with their management responsibilities in a way that conflicted less with the rest of their lives.

\section{Discussion and conclusions}

Our analysis produces two main conclusions that contribute to the existing literature and the relationship between work and private life. Through accounts focusing on work and private life, 18 managers of SSEs in Norway and Sweden explained how they relate and experience the intersection between their work and private life. Three analytical categories were identified: conflict as a part of the deal, using management to construct balance, and management identity contributing to enrichment. These categories framed respondent's identity as managers. This identity was understood in terms of doing management, which also expresses the main theme emerging from our analysis.

The first main conclusion is that enrichment, balance and conflict seem to coexist in manager's individual accounts and for them, doing management is what explains this concurrence. While having a heavy workload is accepted as a prerequisite of being a manager, it has consequences for home life. Working long hours is understood as part of the job and part of the role of being a manager. A management identity as part of doing management seems to create an acceptance of long working hours. Overall, it seems that doing management contributes to the minimization and normalization of the conflicting demands of work on private life.

When respondents were doing management, it contributed to their capacity to balance competing demands. Being a manager allowed the participants to be flexible. When they were flexible, they do management. However, the flexibility was primarily used to work more nights and weekends and to fit work around family commitments. This suggests that such flexibility does not actually create balance between work and personal life despite this being the view of the respondents.

A management identity contributed to personal fulfilment, which, in turn, contributed to enrichment. Among respondents, positive and enriching emotions were associated with management identification and strengthened their capacity to do management - when respondents continued to do or reproduce management, they had positive feelings.

In conclusion, it is important to understand working life and private life as multidimensional phenomena that include conflict, enrichment and balance simultaneously and can be assessed through job identification or doing management. This article contributes to the literature on working life by demonstrating the importance of using a holistic approach to work and life in understanding how different spheres of life interact rather than considering them as distinct and isolated fields.

Our second main conclusion constitutes the non-gendered and gendered ways of doing management in a dual-earner society. This research is situated in a Scandinavian context, which may be important in understanding how managers in this study related to work and family and the interface between them (Hagqvist et al., 2018). In comparison to the existing 
literature from other countries, female managers in this study seem to adhere to the same management identity as men and do management as men do. Thus, the managers in this study do not express a gendered way of doing management.

When management was the primary focus, accounts from both men and women in this study are aligned. However, gender differences do exist. Women felt a sense of guilt and stress towards the home and children that was not evident among male respondents; emotions cause additional burden and stress for women but not for men (Hochschild and Machung, 2003). In addition, female managers found relief in being able to be themselves among friends. Thus, gender differentiation was produced by how managers related to the meaning of family and not to work itself. For Scandinavian men and women in our study, managing was the same, only different.

In conclusion, for the interviewed men, doing management confirmed masculine symbolic capital (Huppatz, 2009), while for the women in our study, identifying with a management role meant a strategic use of masculine capital and not a de-feminisation per see. The female managers felt a guilt because they could not undertake their feminine domestic responsibility they felt they should (Acker, 1990). This suggests that the female managers in our study seem to deploy masculine capital strategically, and as such, they do management. This way of working seems to give them satisfaction and even though the domestic sphere was a source of guilt, this was not their main preoccupation in the intersection between work and family. Instead for women managers in our study the focus in the intersection was management related and time spent at work. Women doing management contribute to the further masculinisation of management, and when doing management, both men and women are producing and reproducing masculinity. Thus, this study adds to Huppatz's theory suggesting that women can use and adhere to masculine capital in management, without de-legitimizing their femininity.

It seems, the managers we interviewed tread a narrow line. The hard work they undertake because they are managers is balanced by the enriching feeling of being a manager. The women managers in our study expressed feelings of stress related to the domestic sphere rather than their work. In the end a management identity may be enough to reduce stress related ill health.

From a policy perspective, the findings on how men and women in SSEs do management and adhere to masculine capital suggests that policies encouraging entrepreneurship need to be carefully designed. Government actions to stimulate self-employment must consider the psychosocial working conditions produced by a heavy workload and long working hours as well as conflicts between work and private life. For example, it is important to take into account these aspects when developing grants for self-employment and educational activities for managers of SSEs. One suggestion is to further develop flexible parental leave systems and social security systems among the self-employed to make these employment situations more attractive. Also of importance is that managers receive support to improve their own working conditions and work-life balance from, for example, occupational health services and other human resource consultants. Such support should combine priorities for the business with a manager's personal life goals. Lastly, female entrepreneurship should have a higher profile and engender more discussion in the public sphere. This could increase the number of women in self-employment and lead to a change in the masculine norm in management.

These data are based on 18 interviews in which nine were business owners and nine were managers acting as company leaders. The fact that not all the participants were business owners must be taken into consideration. The interviews were conducted in the context of 
WHM among small-scale entrepreneurs, which might impact on the stories the interviewees chose to tell and what perspectives they brought to the interviews. That is, the interviewed women might identify with other norms as well, even though this was not evident in the interview material we analysed. This sample, however, provides particular insights and reflections on the types of dilemmas and priorities these managers face in the intersection between work and family. The generalizability of these findings should be examined in future research. The purpose of qualitative research is not to extend findings derived from selected samples to people at large but rather to transform and apply the findings to similar situations in similar contexts (Polit and Beck, 2004). We accept that any interpretation is one of many possible interpretations, but the findings in this article should be understood as relevant to managers of SSEs in similar contexts. A particular strength of the evidence presented in this article is that the managers are drawn from different types of SSEs and sectors and varied in terms of gender and age.

\section{Acknowledgement}

The authors want to express their gratitude to AFA Insurance, the Swedish work environment authority, and the Swedish Research Council for Health, working life and welfare for financing this study. We owe particular gratitude to the managers of SSEs in Norway and Sweden who generously shared their experiences with us.

\section{Funding}

AFA Insurance (Grant No. 130190), the Swedish work environment authority (Grant No. 2015/033753-31), and the Swedish Research Council for Health, working life and welfare (Grant No. 2018-01190). 


\section{References}

Acker J (1990) Hierarchies, jobs, bodies: A theory of gendered organizations. Gender and Society, 4(2): 139-158. doi:10.1177/089124390004002002

Acker J (1992) From sex roles to gendered institutions. Contemporary sociology, 21(5): 565569. doi: $10.2307 / 2075528$

Acker J (2006) Inequality regimes gender, class, and race in organizations. Gender and Society, 20(4): 441-464. doi:10.1177/0891243206289499

Annink A (2017) From social support to capabilities for the work-life balance of independent professionals. Journal of Management and Organization, 23(2): 258-276. doi:10.1017/jmo.2016.53

Annink A, Den Dulk L, and Amorós JE (2016) Different strokes for different folks? The impact of heterogeneity in work characteristics and country contexts on work-life balance among the self-employed. International Journal of Entrepreneurial Behavior and Research, 22(6): 880-902. doi:10.1108/IJEBR-04-2016-0127

Beutell NJ (2007) Self-employment, work-family conflict and work-family synergy: Antecedents and consequences. Journal of Small Business and Entrepreneurship, 20(4): 325-334. doi:10.1080/08276331.2007.10593403

Bianchi SM, and Milkie MA (2010) Work and family research in the first decade of the 21st century. Journal of Marriage and Family, 72(3): 705-725. doi:0.1111/j.17413737.2010.00726.x

Bornberger-Dankvardt S, Ohlson CG, and Westerholm P (2003) Arbetsmiljö och hälsoarbete $i$ småföretag - försök till helhetsbild [Work environment and occupational health in small business - Seeking the full picture]. Arbetslivsinstitutet Report 2003:1

Boye K (2011) Work and well-being in a comparative perspective -The role of family policy. European sociological review, 27(1): 16-30. doi:org/10.1093/esr/jcp051

Bunk JA, Dugan AG, D’Agostino AL, and Barnes-Farrell JL (2012) Understanding work-tofamily conflict among self-employed workers: Utilising a cognitive appraisal framework. Journal of Entrepreneurship, 21(2): 223-251. doi:10.1177/0971355712449790

Byron K (2005) A meta-analytic review of work-family conflict and its antecedents. Journal of Vocational Behavior, 67(2): 169-198. doi:10.1016/j.jvb.2004.08.009

Carbin M, Overud J, and Kvist E. (2017) Feminism som lönearbete [Feminins as paid work]. Stockholm: Leopard förlag.

Connell RW (2009) Om genus (C. Hjukström and A. Sörmark, Trans. 2nd ed.). Cambridge: Polty Press.

Crompton R, and Lyonette C (2006) Work-life 'balance' in Europe. Acta Sociologica, 49(4): 379-393. doi: $10.1177 / 0001699306071680$

Denzin NK (2001) The reflexive interview and a performative social science. Qualitative research, 1(1): 23-46. doi:10.1177/146879410100100102

Duvander AZ, Lappegard T, and Andersson G (2010). Family policy and fertility: fathers' and mothers' use of parental leave and continued childbearing in Norway and Sweden. Journal of European Social Policy, 20(1): 45-57. doi:10.1177/0958928709352541

Eikhof DR, Warhurst C, and Haunschild A (2007) Introduction: What work? What life? What balance?: Critical reflections on the work-life balance debate. Employee Relations, 29(4): 325-333. doi:10.1108/01425450710839452

Engman F, Nordin A, and Hagqvist E (2017) Obalans mellan arbetet och privatlivet bland offentliganställda: betydelsen av kontroll och socialt stöd på arbetsplatsen.

Socialmedicinsk tidskrift, 94(5), 610-622. 
Eurofound (2017) Exploring self-employment in the European Union. Retrieved 2018-02-07 from: https://www.eurofound.europa.eu/publications/report/2017/exploring-selfemployment-in-the-european-union

European Union (2003) Official Journal of the European Union (OJL). Retrieved from http://europa.eu.int/eur-lex/en/oj/.

Fahlén S (2014) Does gender matter? Policies, norms and the gender gap in work-to-home and home-to-work conflict across Europe. Community, Work and Family, 17(4): 371391. doi:10.1080/13668803.2014.899486

Fogelberg Eriksson A (2016) Chefers föreställningar om ledarskap och kön. In PA Ellström, A Fogelberg Eriksson, H Kock, and A Wallo (Eds.) Mot ett förändrat ledarskap?Om chefers arbete och ledarskap i ett organisationsperspektiv. Lund: Studentlitteratur.

Gareis KC, Barnett RC, Ertel KA, and Berkman LF (2009) Work-Family Enrichment and Conflict: Additive Effects, Buffering, or Balance? Journal of Marriage and Family, 71(3): 696-707. doi:10.1111/j.1741-3737.2009.00627.x

Graneheim UH, Lindgren BM, and Lundman B (2017) Methodological challenges in qualitative content analysis: A discussion paper. Nurse Education Today, 56: 29-34. doi:10.1016/j.nedt.2017.06.002

Graneheim UH, and Lundman B (2004) Qualitative content analysis in nursing research: concepts, procedures and measures to achieve trustworthiness. Nurse Education Today, 24(2): 105-112. doi:10.1016/j.nedt.2003.10.001

Greenhaus JH, and Beutell NJ (1985) Sources of conflict between work and family roles. Academy of Management Review, 10(1): 76-88. doi:10.5465/AMR.1985.4277352

Greenhaus JH, and Powell GN (2006) When work and family are allies: A theory of workfamily enrichment. Academy of Management Review, 31(1): 72-92. doi:10.5465/AMR.2006.19379625

Grönlund A (2007a) Egenkontroll som friskfaktor och riskfaktor: det gränslösa arbetet i Västeuropa och Sverige. Arbetsmarknad and Arbetsliv, 13(2): 11-25.

Grönlund A (2007b) More control, less conflict? Job demand-control, gender and workfamily conflict. Gender, Work and Organization, 14(5); 476-497. doi:j.14680432.2007.00361.x

Gunnarsson K, Vingård E, and Josephson M (2007) Self rated health and working conditions of small-scale enterprisers in Sweden. Industrial Health, 45(6): 775-780. doi:10.2486/indhealth.45.775

Hagqvist E (2016). The juggle and struggle of everyday life. Gender, division of work, workfamily perceptions and well-being in different policy contexts. (PhD), Mid Sweden University, Östersund. (244)

Hagqvist E, Gillander Gådin K, and Nordenmark M (2017). Work-Family Conflict and WellBeing Across Europe: The Role of Gender Context. Social Indicators Research, 132(2), 785-797. doi:10.1007/s11205-016-1301-x

Hagqvist E, Toivanen S, and Bernhard-Oettel C (2018). Balancing Work and Life When SelfEmployed: TheRole of Business Characteristics, Time Demands, and Gender Contexts. Social Sciences, 7(8), 139.

Hagqvist E, Toivanen S, and Vinberg S (2015). Time strain among employed and selfemployed women and men in Sweden. Society, Health and Vulnerability, 6. doi:10.3402/shv.v6.29183

Hasle P, and Limborg, HJ (2006) A review of the literature on preventive occupational health and safety activities in small enterprises. Industrial Health, 44(1): 6-12.

doi:10.2486/indhealth.44.6 
Hedlund M, Landstad BJ, and Vinberg S (2017). Tightrope walking: external impact factors on workplace health management in small-scale enterprises. Society, Health and Vulnerability, 8(sup1), 1350551. doi:10.1080/20021518.2017.1350551

Henrekson M, and Stenkula M (2009) Entrepreneurship and public policy, IFN Working Paper No. 804. Stockholm: Research institute of industrial economics.

Hilbrecht M, and Lero DS (2014) Self-employment and family life: Constructing work-life balance when you're 'always on'. Community, Work and Family, 17(1), 20-42. doi:10.1080/13668803.2013.862214

Hochschild A, and Machung A (2003) The second shift: Working parents and the revolution at home. New York: Penguin group.

Holmquist C, and Sundin E (2002) Kvinnors företagande - Siffror och synliggörande. In HC and E Sundin (Eds.), Företagerskan. Om kvinnor och entreprenörskap. Stockholm: SNS Förlag.

Hundley G (2001) Why and when are the self-employed more satisfied with their work? Industrial Relations: A Journal of Economy and Society, 40(2): 293-316. doi:10.1111/0019-8676.00209

Huppatz K (2009) Reworking bourdieu's Capital': Feminine and female capitals in the field of paid caring work. Sociology, 43(1): 45-66. doi:10.1177/0038038508099097

Härenstam A (2009) Exploring gender, work and living conditions, and health-suggestions for contextual and comprehensive approaches. Scandinavian Journal of Work, Environment and Health, 35(2): 127-33. doi:10.5271/sjweh.1308

Johansson Sevä I, and Öun I (2015) Self-Employment as a Strategy for Dealing with the Competing Demands of Work and Family? The Importance of Family/Lifestyle Motives. Gender, Work and Organization, 22(3): 256-272. doi:10.1111/gwao.12076

Landstad BJ, Hedlund M, and Vinberg S (2017). How managers of small-scale enterprises can create a health promoting corporate culture. International Journal of Workplace Health Management, 10(3), 228-248. doi:10.1108/IJWHM-07-2016-0047

Loscocco KA (1997) Work-family linkages among self-employed women and men. Journal of Vocational Behavior, 50(2): 204-226. doi:10.1006/jvbe.1996.1576

Luchman JN, and González-Morales MG (2013) Demands, control, and support: A metaanalytic review of work characteristics interrelationships. Journal of Occupational Health Psychology, 18(1): 37. doi:10.1037\%2Fa0030541

Lunau T, Bambra C, Eikemo TA, van der Wel KA and Dragano N (2014) A balancing act? Work-life balance, health and well-being in European welfare states. The European Journal of Public Health, 24(3): 422-427. doi: 10.1093/eurpub/cku010

McGinnity F, and Calvert E (2009) Work-life conflict and social inequality in Western Europe. Social Indicators Research, 93(3): 489-508. doi:10.1007/s11205-008-9433-2

Nordenmark M, Vinberg S, and Strandh M (2012). Job control and demands, work-life balance and wellbeing among self-employed men and women in Europe. Voulnerable groups and inclusion, 3. doi:10.3402/vgi.v3i0.18896

Parasuraman S, Purohit YS, Godshalk VM, and Beutell NJ (1996) Work and family variables, entrepreneurial career success, and psychological well-being. Journal of Vocational Behavior, 48(3): 275-300. doi:10.1006/jvbe.1996.0025

Patton MQ (2002) Qualitative Research and Evaluation Methods: SAGE Publications.

Polit DF, and Beck, CT (2004) Nursing research, principles and methods (7 ed.). Philadelphia, PA: Lippincott Williams and Wilkins.

Stephan U, and Roesler U (2010) Health of entrepreneurs versus employees in a national representative sample. Journal of Occupational and Organizational Psychology, 83(3): 717-738. doi:10.1348/096317909X472067 
Stephan, U. (2018). Entrepreneurs' mental health and well-being: a review and research agenda. Academy of Management Perspectives(ja).

The European Institute for Gender Equality (2013) Gender equality index report. European Union

Thévenon O (2011) Family policies in OECD countries: A comparative analysis. Population and Development Review, 37(1): 57-87. doi:10.1111/j.1728-4457.2011.00390.x

West C, and Zimmerman DH (1987) Doing gender. Gender and Society, 1(2): 125-151. doi:10.1177/0891243287001002002

Wheatley D (2017) Employee satisfaction and use of flexible working arrangements. Work, employment and society, 31(4): 567-585. doi:10.1177/0950017016631447

Wilkinson K, Tomlinson J, and Gardine, J (2017) Exploring the work-life challenges and dilemmas faced by managers and professionals who live alone. Work, employment and society, 31(4): 640-656. doi:10.1177/0950017016677942 
Table 1. Description of interviewees

\begin{tabular}{lcc} 
& Women & Men \\
\hline $\begin{array}{l}\text { Managers in total } \\
\text { Country } \\
\quad \text { Norway }\end{array}$ & 9 & 9 \\
$\quad$ Sweden & 4 & 4 \\
Age & 5 & 5 \\
$<40$ & & \\
$41-50$ & 1 & 1 \\
$51-61$ & 5 & 5 \\
$>61$ & 3 & 1 \\
& 0 & 2
\end{tabular}

Education

High school

Vocational training school

University

$\begin{array}{ll}2 & 2 \\ 1 & 4 \\ 6 & 3\end{array}$

Civil status

Married/cohabiting

Single

Children living in the home

$\begin{array}{ll}7 & 7\end{array}$

$2 \quad 2$

Years in the enterprise

$\begin{array}{lll}<5 & 3 & 1 \\ 6-10 & 3 & 5 \\ >11 & 2 & 4\end{array}$

Branches

Building and

24

construction/industry

Service delivery

Owner of the enterprise

$7 \quad 5$

$2 \quad 7$


Table 2. Sub-categories, categories and theme.

\begin{tabular}{|c|c|c|}
\hline Sub-categories & Categories & Theme \\
\hline $\begin{array}{l}\text { Always on } \\
\text { Time on work } \\
\text { Job identification } \\
\text { Private life }\end{array}$ & $\begin{array}{l}\text { Conflict as a part of } \\
\text { the deal }\end{array}$ & \multirow{3}{*}{ Doing managemen } \\
\hline $\begin{array}{l}\text { Flexibility } \\
\text { Fit work around } \\
\text { family }\end{array}$ & $\begin{array}{l}\text { Using management } \\
\text { to construct balance }\end{array}$ & \\
\hline $\begin{array}{l}\text { Affecting } \\
\text { enrichment } \\
\text { Instrumental } \\
\text { enrichment } \\
\text { Social support }\end{array}$ & $\begin{array}{l}\text { Management identity } \\
\text { contributing to } \\
\text { enrichment }\end{array}$ & \\
\hline
\end{tabular}

